\title{
Biochemical role of phytoestrogen (Chrysin) against N-methyl nitrosourea (NMU)- induced proliferative lesions in mammary glands of postmenopausal female rat
}

\author{
Amal A. A. El-Kirsh ${ }^{1}$, Hanan M. F. Abd El-Wahab ${ }^{1}$, Hala F. Abd-Ellah ${ }^{2}$, Nagwa I. Y. \\ Hassanin ${ }^{1}$, Nehad N. H. Shosha ${ }^{1}$
}

1. Biochemistry and Nutrition Department, Faculty of Women for Arts Science and Education, Ain Shams University.

2. Zoology Department, Faculty of Women for Arts Science and Education, Ain Shams University

\begin{abstract}
This study aimed to investigate the role of the phytoestrogen (chrysin) in the treatment or protection of NMU-induced preneoplastic lesions in mammary glands of postmenopausal female rats. Rats $(n=105)$ were divided into seven groups ( $n=15 /$ group); group1(negative control group).Groups $2 \& 3$ (positive control groups), rats were injected intraperitoneally (i.p.) with 4 doses of NMU ( $75 \mathrm{mg} / \mathrm{kg}$ b.w.,once/5days) before or after oral administration of glycofurol. Groups $4 \& 5$ (treatment groups),rats received 4 doses of NMU (75 mg/kg b.w., once/5days,i. p.), left for 6 weeks then followed by 3 doses, per week, of chrysin (125 or 250 $\mathrm{mg} / \mathrm{kg}$ b.w., orally; p.o), respectively, for another 6 weeks. Groups $6 \& 7$ (protective groups), rats received 3 doses, per week, of chrysin(125 or $250 \mathrm{mg} / \mathrm{kg} \mathrm{b.w.,p.o.),} \mathrm{for} 6$ weeks then followed by 4 doses of NMU ( $75 \mathrm{mg} / \mathrm{kg}$ b.w., once/5days, i.p.) then left for another 6 weeks. The NMU injection caused significant decrease in PLT count, lymphocytes \%, Hb, $\mathrm{MCH}$, MCHC, $\mathrm{E}_{2}$, TAC levels as well as GST and CAT activities. The results also showed that NMU significantly elevated WBC count, granulocytes $\%$, monocytes \%, MCV, RDW\%, CRP, CEA levels and arginase activity. Either treatment or protection with chrysin modulated the adverse effects of NMU and ameliorated the change in the biochemical parameters. The biochemical observations were also confirmed by histological studies. In conclusion, phytoestrogens may relieve the severity of postmenopausal pre-cancerous disorders, especially when consumed in high dose for a while before the incidence of lesions.
\end{abstract}

Key Words: Phytoestrogen; Chrysin; NMU; mammary; Rat.

\section{Introduction}

Globally breast cancer (BC) is the most often diagnosed cancer and the leading cause of cancer death among women accounting for $23 \%$ of the total cancer cases and $14 \%$ of the cancer deaths (Meeran et al., 2012). Around 5-10\% of all BC are caused by an inherited genetic mutation. Remaining 90-95\% of BC is caused by other risk factors (Srinivasan and Manoharan, 2011). The etiology of $\mathrm{BC}$ is multi-factorial and the major risk factors of this disease include sex, age, child bearing, hormones, high fat diet, tobacco, alcohol intake, obesity and environmental factors such as radiation (Ferlay et al., 2010). The most important risk factors are female gender and age. Approximately two out of three breast cancer cases are found after 55 years of age; among women between 75 and 79 years of age, the incidence is one case for every 300 women per year (Biglia et al., 2004)

corresponding author: Hanan M. F.Abd El-Wahab, Biochemistry and Nutrition Department, Faculty of Women for Arts Science and Education,, Ain Shams University, Cairo, Egypt. E-mail: mf_nana@ hotmail.com 
NMU is a direct-acting alkylating agent that interacts with DNA. Accumulation of mutations may enhance cancer risk in target organs or cause cell death in susceptible tissues or cells when excessive DNA damage is not repaired. NMU has been most extensively utilized for the induction of mammary cancer in rats. NMU-induced rat mammary tumors possess many similarities to those of human BC (Tsubura et al., 2011). NMU does not require metabolic activation to form DNA adducts and has a very short half- life. The NMU induced mammary tumors are more estrogen dependent locally aggressive and able to metastasize (Thompson and Adlakha, 1991). Metastatic BC is a life-threatening stage of cancer and is the leading cause of death in advanced BC patients. Estrogen signaling and estrogen receptor (ER) are implicated in BC progression and the majority of the human breast cancers start out as estrogen dependent (Saha Roy andVadlamudi, 2012).

Phytoestrogens are secondary polyphenolic plant substances (Davis et al., 2008), with similarities to 17-beta estradiol $\left(\mathrm{E}_{2}\right)$ in chemical structure (Pilsakova et al., 2010).Phytoestrogens constitute a group of plant-derived estrogens possessing significant estrogen agonist/ antagonist activity. These, naturally occurring molecules, include the isoflavones, lignans, coumestanes, stilbens and the flavonoids quercetin and kaempherol. Their effects mediated via the interaction with ER subtypes ER $\alpha$ and ER $\beta$. They are characterized by high tissue specificity and dose-dependent activity (Moutsatsou, 2007). Chrysin (5,7dihydroxyflavone), is a natural flavone occurring in various sources such as propolis and honey (Gambelunghe et al., 2003). It has been demonstrated to have antiinflammatory (Cho et al., 2004), antioxidant effects (Woodman and Chan, 2004) and also has shown to have cancer chemoprotective activity via induction of apoptosis in diverse range of human and rat cell types (Khoo et al., 2010).

Epidemiologic studies have suggested that high consumption of phytoestrogens, mostly soy and unrefined grain products, may lower the risk of some cancers such as colorectal, prostate, and breast cancer (Alipour et al., 2015). As well, ecologic observations have confirmed that the lower incidence of BC among Asian women may be related to the more frequent use of phytoestrogens (Mense et al., 2008) Phytoestrogens are able to bind to ERs invitro and, thereby induce or modulate the estrogen signaling pathway (Setchell, 2001).In vitro work showed either a weak proliferative effect of soy isoflavones on $\mathrm{BC}$ cell or the blockage of proliferative effects of $\mathrm{E}_{2}$ on these cells (Pitkin,2012). The aim of this study was to evaluate the effect of two doses of chrysinas a phytoestrogen in modulating bengin proliferative lesions induced by NMU in postmenopausal female rats.

\section{Materials and Methods}

\subsection{Chemicals:}

N-methyl-N-nitrosourea(NMU), chrysin (chry) (5,7-dihydroxyflavone) and tetraethylene glycol (glycofurol) were purchased from Sigma chemical Company (St Louis, MO 63103, USA). N-methyl-N-nitrosourea was given intraperitoneally (i.p.) at dose level of $75 \mathrm{mg} / \mathrm{kg}$ b.w. (Ogur and Tekbas, 2011) and freshly prepared by dissolving in physiological saline containing $0.05 \%$ acetic acid according to Allred et al. (2004). Chrysin was given orally (per os, p.o.) at dose levels of $125 \mathrm{mg} / \mathrm{kg} \mathrm{b.w}$. or $250 \mathrm{mg} / \mathrm{kg} \mathrm{b.w.} \mathrm{according} \mathrm{to}$ Srinivasan and Manoharan (2011) and was freshly prepared by dissolving in tetraethylene glycol (glycofurol) according to Kawase et al. (2009).

\subsection{Animals:}

One hundred and five adult female albino rats "Sprague-Dawely" weighing 250-280 g, obtained from the animal house of El- Salam farm, Giza, Egypt were used in this study. 
After one week of acclimatization, rats were housed individually in animal care facility with constant environment in controlled stainless steel cages, at a room temperature $\left(25^{\circ} \mathrm{C} \pm 5{ }^{\circ} \mathrm{C}\right)$ and relative humidity $(50 \% \pm 10 \%)$, with 12 hour light/dark cycles.

\subsection{Experimental design:}

Rats were randomly divided into seven groups with 15 rats each with similar average weight, and were provided with standard commercial diet (NRC, 1995) and water ad libitum. Rats were weighed weekly to adjust the per oral dose of chrysin and intraperitoneal dose of NMU. The groups were as the following:

Group1 (Negative control): Half of rats received 4 i.p. injections of physiological saline one dose every 5 days, then left for 6 weeks, followed by 3 oral doses( every other day per week) of distilled water for another 6 weeks. The other half received 3 oral doses ( every other day per week) of distilled water for 6 weeks then followed by 4 i.p. injections of physiological saline a dose every 5 days and then left for another 6 weeks.

Group2 (NMU/glycofurol): Rats received 4 i.p. doses of NMU (75 mg/kg b.w.)each dose every 5 days and then left for 6 weeks and followed by 3 oral doses (every other day per week)of glycofurol for another 6 weeks.

Group3 (glycofurol/NMU): Rats received 3 oral doses (every other day per week) of glycofurol for 6 weeks, followed by 4 i.p. doses of NMU $(75 \mathrm{mg} / \mathrm{kg} \mathrm{b.w.)}$ one dose every 5 days, then left for another 6 weeks.

Groups 4 (NMU/chry.LD) \& 5 (NMU/chry.HD): Rats received NMU (as in Group2), then left for 6 weeks followed by 3 oral doses (every other day per week) of chrysin $(125 \mathrm{mg} / \mathrm{kg}$ b.w. or $250 \mathrm{mg} / \mathrm{kg} \mathrm{b.w.),respectively,} \mathrm{for} \mathrm{another} 6$ weeks.

Groups 6 (chry.LD/NMU) \& 7 (chry.HD/NMU): Rats received 3 oral doses (every other day per week) of chrysin ( $125 \mathrm{mg} / \mathrm{kg} \mathrm{b.w.} \mathrm{or} 250 \mathrm{mg} / \mathrm{kg} \mathrm{b.w.),} \mathrm{respectively,} \mathrm{for} 6$ weeks and followed by NMU (as in Group3), then left for another 6 weeks. All animals received human care in compliance with the internationally valid guidelines of the Animal Care and Use Ethic Committee of Ain Shams University, Cairo, Egypt.

\subsection{Biochemical studies:}

At the end of the experimental period (12 weeks), animals were sacrificed after 12 hours fasting. Blood samples were collected from hepatic portal vein, left for $15 \mathrm{~min}$. at $37{ }^{\circ} \mathrm{C}$ then centrifuged at 4000 r.p.m for $20 \mathrm{~min}$. for serum separation which was stored at $-20^{\circ} \mathrm{C}$ in plastic vials until analysis. Part of blood from each rat was collected into tubes containing EDTA for complete blood picture determination using Mindray Vet-BC2800 (Mindray International/ Electronic company, China).

Serum C-reactive protein (CRP) was estimated by means of particle enhanced turbid metric immunoassay kit (Spectrum company) according to Okamura et al. (1990). Serum carcinoemberyonic antigen (CEA) and estrogen level (as estradiol, $\mathrm{E}_{2}$ ) were determined using ELISA kit (Glory Science company) according to Abeyounis andMilgrom (1972) and Batzer (1980), respectively. Serum total antioxidant capacity (TAC), nitric oxide (NO) and lipid preoxidation (as malondialdehyde, MDA) were estimated by colorimetric method kit developed by Biodiagnostic company, Giza, Egypt according to Koracevic et al. (2001); Green et al. (1982); Ohkawa et al. (1979), respectively. Furthermore, arginase, glutathiones-transferase (GST) and catalase (CAT) activities were determined in serum by colorimetric method kit supplied by Biodiagnostic company, Giza, Egypt according to Mellerup (1967); Habig et al. (1974); Aebi (1984), respectively. 


\subsection{Histopathological Examination:}

Tissue specimens from the mammary glands of the experimental groups were immediately excised, washed using physiological saline solution, fixed in $10 \%$ neutral buffered formalin for 24 hours, dehydrated in ascending ethanol series, cleared in xylene and

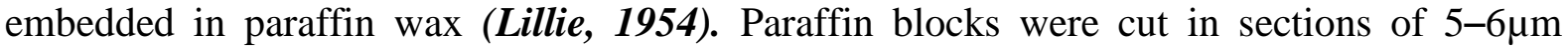
thickness using a rotatory microtome and stained with hematoxylin and eosin (H\&E) stain. Examination of sections from all groups under light microscope and assessment of various groups was performed (Drury and Wellington,1980).

\subsection{Statistical analysis:}

The data were presented as mean \pm standard error. One-way analysis of variance followed by post hoc-least significant difference analysis was performed using the statistical package for social science (SPSS) version 16 to compare all the treated groups. The values of $P$ $<0.05$ and $P<0.001$ were considered significant and very highly significant respectively. Percent of change was calculated as difference between the experimental and normal control group or positive control groups.

\section{Results and Discussion}

\subsection{Results}

\subsubsection{Biochemical studies:}

Table (1) illustrated that, injection with NMU led to significant decrease in PLT count, by $-24.25 \%$ in group 2 (NMU/glycofurol) rats and non-significant decrease in group 3 glycofurol/NMU) rats but a significant increase $(P<0.001)$ in WBC count by $73.36 \%$ for (NMU/glycofurol) and $40.65 \%$ for (glycofurol/NMU) rats compared with group1(negative control rats). PLT count was increased significantly in rats treated with high dose of chrysin, (NMU/chry.HD) by $33.21 \%$ compared to rats of its positive control group (NMU/glycofurol). Furthermore, all rats in the treatment and protective groups showed significant decrease in the WBC count as compared with their respective positive control groups. On the other hand treatment and protection by chrysin induced non-significant change in PLT and WBC count compared to negative control rats. Also, injection with NMU reduced the percentage of lymphocytes and elevated the percentage of monocytes and granulocytes as compared to negative control group. The changes recorded were at $P<0.001$ for group3 (glycofurol/NMU) and $P<0.05$ for group2 (NMU/glycofurol). The obtained data revealed that, rats of protective groups showed significant decrease in monocytes $\%$ as compared with rats of group3. The levels of lymphocytes and granulocytes of rats from group5 and the monocytes from (groups 4, 5, $6 \& 7$ ) tended to have non-significant increase or decrease as compared with negative control group (group1).

Table (2), indicated that, the injection with NMU led to decrease in hemoglobin $(\mathrm{Hb})$ concentration such decrease was significant by $-9.94 \%$ in group2 (NMU/glycofurol) and very highly significant by $-15.56 \%$ in group3 (glycofurol/NMU) as compared to negative control rats. Furthermore, injection with NMU significantly increased MCV level and RDW\% and significantly decreased $\mathrm{MCH}$ and $\mathrm{MCHC}$ levels at $P<0.001$. Only the treatment group (NMU/chry.HD) showed normalization of $\mathrm{Hb}$ level compared to the treatment group (NMU/chry.LD) and protective groups. Compared to the negative control group, data also revealed that, group6 (chry.LD/NMU) and group7 (chry.HD/NMU) 
provided considerable improvement on the MCV level. Meanwhile, group5 (NMU/chry.HD) provided a pronounced improvement on the $\mathrm{MCH}$, and RDW\% levels.

Table (1): Platelet and white blood cell (WBC) counts, and the percent of lymphocytes, monocytes and granulocytes in different experimental groups

\begin{tabular}{ccccccc}
\hline \multicolumn{2}{c}{ Groups } & \multicolumn{5}{c}{ Parameters } \\
\cline { 2 - 7 } & & PlateletX10 $/ \mathrm{L}$ & WBCX10 $/ \mathrm{L}$ & Lymphcytes\% & Monocytes \% & Granulocytes\% \\
\hline $\begin{array}{c}\text { Negativec } \\
\text { ontrol } \\
\text { group }\end{array}$ & Group1 & $767 \pm 73.70$ & $4.28 \pm 0.34$ & $43.56 \pm 2.33$ & $4.72 \pm 0.50$ & $51.94 \pm 2.31$ \\
\hline $\begin{array}{c}\text { Positive } \\
\text { control } \\
\text { groups }\end{array}$ & Group2 & $581 \pm 60.44^{\mathrm{a}}$ & $7.42 \pm 0.59^{1}$ & $31.05 \pm 2.13^{\mathrm{a}}$ & $6.50 \pm 0.31^{\mathrm{a}}$ & $62.42 \pm 2.45^{\mathrm{a}}$ \\
\hline $\begin{array}{c}\text { Treatment } \\
\text { groups }\end{array}$ & Group4 & $649 . \pm 38.91$ & $5.00 \pm 0.29^{\mathrm{b}}$ & $30.76 \pm 4.33^{\mathrm{a}, \mathrm{c}}$ & $5.86 \pm 0.43$ & $63.14 \pm 4.79^{\mathrm{a}, \mathrm{c}}$ \\
\hline $\begin{array}{c}\text { Protective } \\
\text { groups }\end{array}$ & Group6 & $765 \pm 37.32^{\mathrm{b}}$ & $4.17 \pm 0.81^{2, \mathrm{c}}$ & $27.96 \pm 1.28^{\mathrm{a}, \mathrm{c}}$ & $5.22 \pm 0.40^{\mathrm{b}, \mathrm{c}}$ & $68.18 \pm 2.46^{1}$ \\
\hline
\end{tabular}

Values are represented as means \pm SE.

Group1,negative control; Group2, NMU/glycofurol; Group3, glycofurol/NMU; Group4, NMU/chry.LD;

Group5, NMU/chry.HD; Group6, chry.LD/NMU\& Group7, chry.HD/NMU.

Numbers $1,2 \& 3$ represent statistical differences with groups $1,2 \& 3$, respectively at $P<0.001$.

Letters a, b, c, d \& e represent statistical differences with groups $1,2,3,4 \& 5$, respectively at $P<0.05$.

Table (2): Levels of hemoglobin (Hb), mean corpuscular volume (MCV), mean corpuscular hemoglobin (MCH), mean corpuscular hemoglobin concentration (MCHC) and Red cell distribution width (RDW) in different experimental groups

\begin{tabular}{ccccccc}
\hline \multirow{2}{*}{ Groups } & \multicolumn{5}{c}{ Parameters } \\
\cline { 2 - 6 } & $\mathrm{Hb}(\mathrm{g} / \mathrm{dl})$ & $\mathrm{MCV}(\mathrm{fl})$ & $\mathrm{MCH}(\mathrm{Pg})$ & $\mathrm{MCHC}(\mathrm{g} / \mathrm{dl})$ & $\mathrm{RDW} \%$ \\
\hline $\begin{array}{c}\text { Negative } \\
\text { control } \\
\text { group }\end{array}$ & Group1 & $13.88 \pm 0.41$ & $51.48 \pm 0.94$ & $19.94 \pm 0.64$ & $38.92 \pm 1.82$ & $11.46 \pm 0.30$ \\
\hline $\begin{array}{c}\text { Positive } \\
\text { control }\end{array}$ & Group2 & $12.50 \pm 0.24^{\mathrm{a}}$ & $56.22 \pm 0.73^{1}$ & $16.78 \pm 0.18^{1}$ & $30.58 \pm 0.45^{1}$ & $15.74 \pm 0.84^{1}$ \\
groups & Group3 & $11.72 \pm 0.16^{1}$ & $55.90 \pm 0.99^{\mathrm{a}}$ & $17.44 \pm 0.20^{1}$ & $32.84 \pm 0.50^{1}$ & $15.78 \pm 0.56^{1}$ \\
\hline $\begin{array}{c}\text { Treatment } \\
\text { groups }\end{array}$ & Group4 & $12.90 \pm 0.22^{\mathrm{a}, \mathrm{c}}$ & $53.40 \pm 0.80^{\mathrm{b}}$ & $18.40 \pm 0.34^{\mathrm{a}, \mathrm{b}}$ & $34.12 \pm 0.16^{1, \mathrm{~b}}$ & $13.72 \pm 0.44^{\mathrm{a}, \mathrm{b}, \mathrm{c}}$ \\
\hline $\begin{array}{c}\text { Protective } \\
\text { groups }\end{array}$ & $13.46 \pm 0.38^{3, \mathrm{~b}}$ & $53.86 \pm 1.14$ & $19.24 \pm 0.48^{2, \mathrm{c}}$ & $34.58 \pm 0.66^{1, \mathrm{~b}}$ & $12.44 \pm 0.45^{2,3}$ \\
\hline
\end{tabular}

Values are represented as means \pm SE.

Group1, negative control; Group2, NMU/glycofurol; Group3, glycofurol/NMU; Group4, NMU/chry.LD;

Group5, NMU/chry.HD; Group6, chry.LD/NMU\& Group7, chry.HD/NMU.

Numbers $1,2,3 \& 5$ represent statistical differences with groups $1,2,3 \& 5$, respectively at $P<0.001$.

Letters a, b, c, d \& e represent statistical differences with groups $1,2,3,4 \& 5$, respectively at $P<0.05$. 
Table (3): Concentrations of C-reactive protein (CRP), carcinoembryonic antigen $(C E A)$ and estradiol $\left(E_{2}\right)$ in different experimental groups

\begin{tabular}{ccccc}
\hline \multicolumn{2}{c}{ Groups } & & \multicolumn{3}{c}{ Parameters } \\
\cline { 3 - 5 } & CRP mg/dL & CEA ng/ml & $\mathrm{E}_{2} \mathrm{ng} / \mathrm{ml}$ \\
\hline $\begin{array}{c}\text { Negative control } \\
\text { group }\end{array}$ & Group1 & $6.52 \pm 0.58$ & $0.41 \pm 0.03$ & $2.72 \pm 0.11$ \\
\hline $\begin{array}{c}\text { Positive control } \\
\text { groups }\end{array}$ & Group2 & $17.52 \pm 1.43^{1}$ & $0.82 \pm 0.03^{1}$ & $1.98 \pm 0.08^{1}$ \\
\hline \multirow{2}{*}{ Treatment groups } & Group3 & $19.60 \pm 0.89^{1}$ & $1.06 \pm 0.07^{1,2}$ & $2.28 \pm 0.05^{\mathrm{a}}$ \\
\hline \multirow{2}{*}{ Protective groups } & Group4 & $16.32 \pm 0.78^{1, \mathrm{c}}$ & $0.50 \pm 0.03^{2,3}$ & $2.63 \pm 0.17^{2, \mathrm{c}}$ \\
& Group5 & $10.10 \pm 0.97^{2,3,4, \mathrm{a}}$ & $0.42 \pm 0.01^{2,3}$ & $2.79 \pm 0.13^{2, \mathrm{c}}$ \\
\hline
\end{tabular}

Values are represented as means $\pm \mathrm{SE}$.

Group1, negative control; Group2, NMU/glycofurol; Group3, glycofurol/NMU; Group4, NMU/chry.LD; Group5, NMU/chry.HD; Group6, chry.LD/NMU\& Group7, chry.HD/NMU.

Numbers $1,2,3,4,5 \& 6$ represent statistical differences with groups $1,2,3,4,5 \& 6$, respectively at $P<0.001$. Letters a, c \& f represent statistical differences with groups $1,3 \& 6$, respectivelyat $P<0.05$

Data in table (3) shows that, rats injected with NMU, (NMU/glycofurol) and (glycofurol/NMU) had a significant increase in the levels of serum CRP (by $168.71 \%$ and by $200.61 \%$, respectively) and CEA (by $100.00 \%$ and by $158.54 \%$, respectively) compared to negative control group at $P<0.001$. Table (3) also indicated that, $\mathrm{E}_{2}$ concentration of the positive control groups were significantly decreased by $-27.20 \%$ (NMU/glycofurol) at $P<0.001$ and by $-16.18 \%$ (glycofurol/NMU) at $P<0.05$ as compared to negative control group.Treatment with low dose of chrysin after injection with NMU, (NMU/chry.LD) caused significant decrease in serum CEA concentration by $-39.02 \%$; significant increase in serum $\mathrm{E}_{2}$ concentration by $32.82 \%$ at $P<0.001$ and non-significant decrease in CRP concentration, although, treatment with high dose, (NMU/chry.HD) significantly decreased the concentration of serum CRP by $-42.35 \%$; CEA by $-48.78 \%$ and significantly increased the $\mathrm{E}_{2}$ concentration by $40.90 \%$ at $P<0.001$ as compared with their respective positive control (NMU/glycofurol).

On the other hand, protection by high dose of chrysin, (chry.HD/NMU) decreased level of CRP by $-60.51 \%$ and CEA by $-57.55 \%$ and increased $\mathrm{E}_{2}$ level by $25.00 \%$ than protection by low dose of chrysin, (chry.LD/NMU) that reduced CRP by $-44.80 \%$ and CEA by -20.75 and increased $E_{2}$ level by $26.31 \%$ as compared to their positive control group, (glycofurol/NMU). The high dose, group7 (chry.HD/NMU) of chrysin had a marked significant decrease in serum CRP concentration at $P<0.001$ compared to group4 (NMU/chry.LD). Values of CEA concentration of rats consumed chrysin as high dose, (NMU/chry.HD) and (chry.HD/NMU) were very significantly decreased compared to rats consumed low dose of chrysin as protection, (chry.LD/NMU). The protection with high dose of chrysin, group7 (chry.HD/NMU) nearly restored the CRP and CEA concentration to be near that of negative control group. On the other hand, there were no significant differences in the mean values of $\mathrm{E}_{2}$ concentration among the protective, treatment groups and the negative control group. 
Table (4) shows that, injection with NMU, (NMU/glycofurol) and (glycofurol/NMU) induced significant increase in serum arginase activity (by $74.72 \%$ and $43.47 \%$, respectively), significant decrease in serum GST activity (by $-58.37 \%$ and $44.83 \%$, respectively) and significant decrease in serum CAT activity (by $-88.33 \%$ and $28.87 \%$, respectively) as compared to negative control group at $P<0.001$.All rats received chrysin for treatment either by low (NMU/chry.LD) or high dose (NMU/chry,HD) exhibited significant increase in GST activity by (44.99\% and $60.42 \%$, respectively) and CAT activity (by $113.80 \%$ and $146.55 \%$, respectively) at $P<0.05$ as well as significant decrease in arginase activity (by $-32.19 \%$ and $-34.74 \%$, respectively) at $P<0.001$ when compared to their positive control group (NMU/glycofurol). On the other hand, the activity of serum GST which was recorded in protective groups, (chry.LD/NMU) and (chry.HD/NMU) was significantly increased at $P<0.001$ (by $67.43 \%$ and $101.18 \%$, respectively), while, the activity of CAT was significantly increased (by16.78\% at $P<0.05$ and $34.15 \%$ at $P<0.001$, respectively) when compared to group3 (glycofurol/NMU). It is clear that, there are a very highly significant increase in serum GST and CAT activities and non-significant difference in the mean values of serum arginase activity in protective groups [(chry.LD/NMU) and (chry.HD/NMU)] in comparison to both treatment groups, [(NMU/chry.LD) and (NMU/chry.HD)].

Table (4): Activity of serum arginase, Glutathione-S-transferase (GST) and catalase (CAT) in different experimental groups

\begin{tabular}{|c|c|c|c|c|}
\hline \multirow{2}{*}{ Group } & & \multicolumn{3}{|c|}{ Parameters } \\
\hline & & Arginase U/L & GST U/L & CAT U/L \\
\hline $\begin{array}{l}\text { Negative control } \\
\text { group }\end{array}$ & Group1 & $120.00 \pm 10.85$ & $27.55 \pm 2.87$ & $48.42 \pm 2.61$ \\
\hline \multirow{2}{*}{$\begin{array}{l}\text { Positive control } \\
\text { groups }\end{array}$} & Group2 & $209.67 \pm 10.11^{1}$ & $11.47 \pm 1.68^{1}$ & $5.65 \pm 0.90^{1}$ \\
\hline & Group3 & $172.17 \pm 7.69^{1}$ & $15.20 \pm 0.75^{1}$ & $34.44 \pm 1.59^{1,2}$ \\
\hline \multirow{2}{*}{ Treatment groups } & Group4 & $142.17 \pm 9.70^{2, \mathrm{c}}$ & $16.63 \pm 1.18^{1, b}$ & $12.08 \pm 0.58^{1,3, \mathrm{~b}}$ \\
\hline & Group5 & $136.83 \pm 8.48^{2, \mathrm{c}}$ & $18.40 \pm 0.74^{1, \mathrm{~b}}$ & $13.93 \pm 0.85^{1,3, b}$ \\
\hline \multirow{2}{*}{ Protective groups } & Group6 & $156.17 \pm 15.44^{2, \mathrm{a}}$ & $25.45 \pm 0.89^{2,3,4, \mathrm{e}}$ & $40.22 \pm 2.09^{2,4,5, \mathrm{a}, \mathrm{c}}$ \\
\hline & Group7 & $160.33 \pm 4.32^{2, \mathrm{a}}$ & $30.58 \pm 1.65^{2,3,4,5, f}$ & $46.20 \pm 2.43^{2,3,4,5, \mathrm{f}}$ \\
\hline
\end{tabular}

Values are represented as means \pm SE.

Group1, negative control; Group2, NMU/glycofurol; Group3, glycofurol/NMU; Group4, NMU/chry.LD; Group5, NMU/chry.HD; Group6, chry.LD/NMU\& Group7, chry.HD/NMU.

Numbers 1,2,3,4 \& 5 represent statistical differences with groups1, 2,3,4\& 5, respectively at $P<0.001$.

Letters a, b, c, e \& f represent statistical differences with groups1, 2,3,5 \&6, respectively at $P<0.05$.

Table (5) shows that, injection with NMU (NMU/glycofurol) induced a significant decrease in the TAC level by $-16.21 \%$ at $P<0.001$ as compared to negative control group. Investigations had also shown that, injection with NMU, (NMU/glycofurol) and (glycofurol/NMU) resulted in significant increase in levels of serum MDA by (337.14\% and 465.71, respectively) and serum NO (by $272.68 \%$ and $128.29 \%$, respectively) as compared to negative control group.The MDA and NO levels were significantly lowered at $P<0.001$ in the treatment and protective groups than those in its positive control groups. The percent of change for group4 and group5 from group2 in MDA were $-44.44 \%$ and $-51.47 \%$, respectively but in serum NO was $-14.66 \%$ and$17.54 \%$, respectively. The percent change for group6 and group7 from group3 in MDA 
was $-52.65 \%$ and $-79.17 \%$, respectively but in NO was $-58.97 \%$ and $-60.47 \%$, respectively. However, the values of MDA and NO remained higher than the normal control values. Except for the protective groups, the reduction in NO exceeds the levels found in the negative control group. There was significant elevation $P<0.001$ in the level of serum TAC of protective groups when compared to treatment groups and the level of TAC recorded in the protective groups approached that found in negative control group

Table (5): Levels of serum total antioxidant capacity (TAC), malondialdehyde (MDA), and nitric oxide (NO) in different experimental groups

\begin{tabular}{ccccc}
\hline Groups & & \multicolumn{3}{c}{ Parameters } \\
\cline { 3 - 5 } & TAC mMol/L & MDA nMol/L & NO mMol/L \\
\hline $\begin{array}{c}\text { Negative control } \\
\text { group }\end{array}$ & Group1 & $2.22 \pm 0.059$ & $1.40 \pm 0.068$ & $2.05 \pm 0.152$ \\
\hline $\begin{array}{c}\text { positive control } \\
\text { groups }\end{array}$ & Group2 & $1.86 \pm 0.037^{1}$ & $6.12 \pm 0.767^{1}$ & $7.64 \pm 0.158^{1}$ \\
\hline \multirow{2}{*}{ Treatment groups } & Group3 & $2.11 \pm 0.033^{\mathrm{b}}$ & $7.92 \pm 0.307^{1, \mathrm{~b}}$ & $4.68 \pm 0.166^{1,2}$ \\
\hline \multirow{2}{*}{ Protective groups } & Group5 & $1.94 \pm 0.084^{1, \mathrm{c}}$ & $3.40 \pm 0.311^{1,2,3}$ & $6.52 \pm 0.073^{1,2,3}$ \\
& Group6 & $2.21 \pm 0.037^{2,4,5}$ & $3.75 \pm 0.427^{1,2,3}$ & $1.92 \pm 0.087^{2,3,4,5,}$ \\
& Group7 & $2.23 \pm 0.049^{2,4,5}$ & $1.65 \pm 0.1856^{2,3,6, \mathrm{~d}, \mathrm{e}}$ & $1.85 \pm 0.102^{2,3,4,5}$ \\
\hline
\end{tabular}

Values are represented as means \pm SE.

Group1, negative control; Group2, NMU/glycofurol; Group3, glycofurol/NMU; Group4, NMU/chry.LDGroup5, NMU/chry.HD; Group6, chry.LD/NMU\& Group7, chry.HD/NMU.

Numbers $1,2,3,4,5 \& 6$ represent statistical differences with groups1, 2, 3, 4, $5 \& 6$, respectively at $P<0.001$. Letters a, b, c, d \& e represent statistical differences with groups1, 2, 3, $4 \& 5$, respectively at $P<0.05$.

\subsubsection{Histopathological Studies}

Histopathological analyses were performed on mammary glands from all experimental animals. The results showed that the mammary tissue of negative control rats showed no morphological alterations. The mammary glands showed normal lobular architecture with branched ducts and normal distribution of fat tissue (Figure $1 \mathrm{~A}$ ).

In the case of group 2 (NMU/glycofurol), ductal epithelial hyperplasia (epitheliosis) were observed in multiple ducts and some of the epithelial cells have compressed nuclei (Figure 1 B). In addition, there were cystically dilated ducts with proliferation of the lining epithelium. On the other hand, exfoliation of epithelial cells into the duct were also seen (Figure $1 \mathrm{C}$ ). In group 3 (glycofurol/NMU), the majority of ducts had higher degree of atypical ductal hyperplasia of epithelium (florid hyperplasia) (Figure $1 \mathrm{D}$ ). The epithelial cells within the atypical hyperplasia exhibited hyperchromatic nuclei and dense eosinophilic cytoplasmic staining. Additionally, intraluminal projections of benign epithelial proliferation were detected (Figure $1 \mathrm{E}$ ).

Oral administration of chrysin moderately reduced the severity of histopathological changes in groups 4,5 compared to group2. In group 4, treatment with low dose of chrysin after injection with NMU (NMU/chry.LD) showed that portions of ducts had moderate ductal epithelial proliferation and sloughing of epithelial cells into the dilated ducts (Figure $1 \mathrm{~F}$ ). On the other hand, in group 5, treatment with high dose of chrysin after injection with NMU 
(NMU/chry.HD) showed focal regions of moderate to mild ductal epithelial proliferation (Figure 1G).

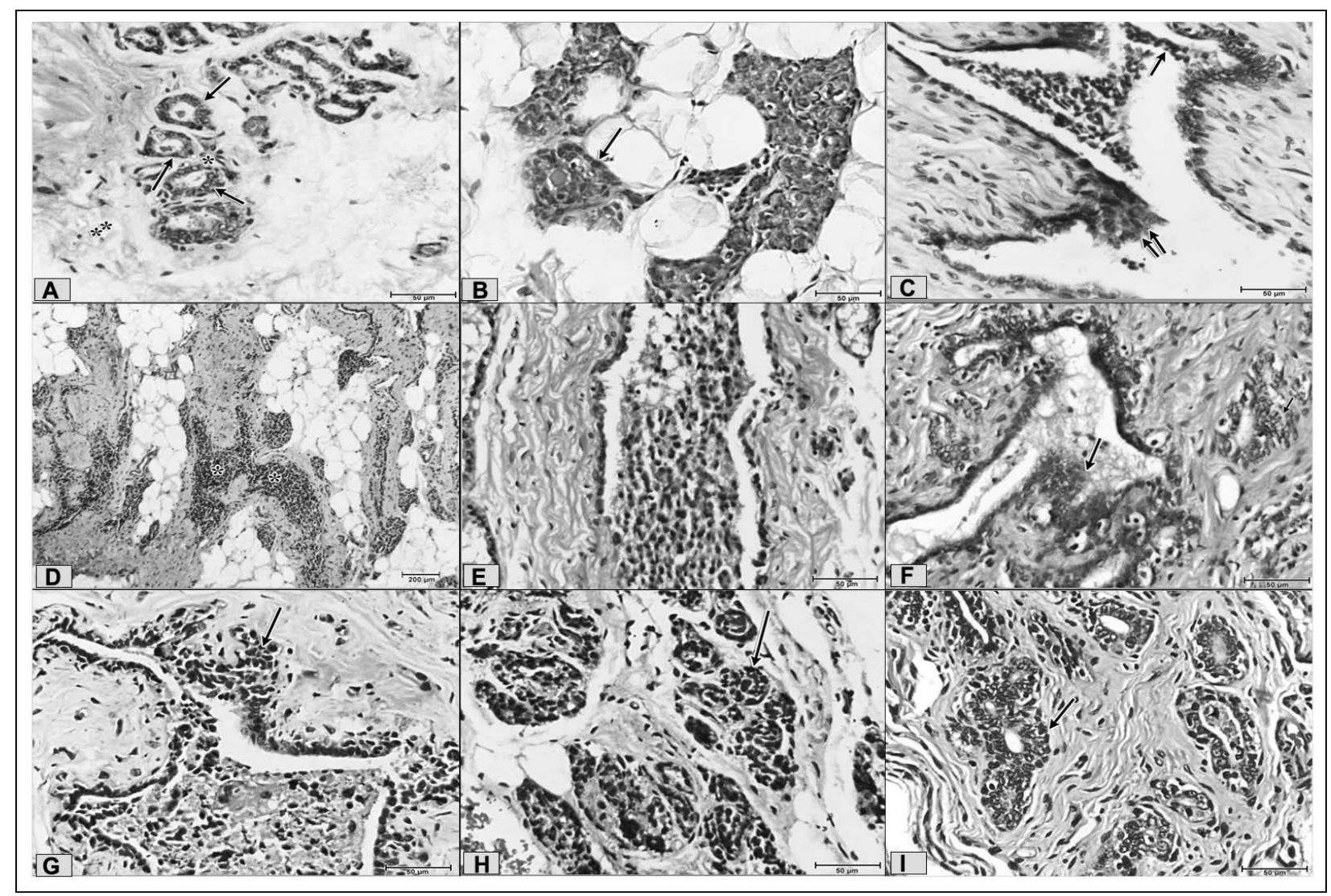

Figure (1) Light micrographs of the mammary glands of female rats. Group1 (Negative control) (A) showing normal lobular architecture with intralobular ducts, lined by a simple cuboidal epithelium (arrows). Note intralobular $(*)$ and interlobular connective tissue $(* *)$. Group 2 (NMU/glycofurol, B\&C) showing (B) atypical ductal epithelial hyperplasias (epitheliosis) (arrows). Note that some of the cells have compressed nuclei (arrowhead). (C) Cystically dilated duct with proliferation of the lining epithelium (arrows) and exfoliation of clusters of epithelial cells into the duct (double arrows). Group3 (glycofurol/NMU, D\&E) showing (D) severe atypical intraductal epithelial hyperplasia (*). Note that the duct lumens are distended with proliferated epithelial cells (florid hyperplasia). (E) intraluminal projection of benign epithelial proliferation. Group 4 (NMU/chry.LD) (F) showing portions of the duct contains moderate proliferation of epithelial cells (arrows) with sloughing of epithelial cells into the dilated duct (arrowhead). Group5 (NMU/chry.HD) (G) showing portions of moderate to mild ductal epithelial proliferation (arrow). Group 6 (chry.LD/NMU) (H) showing mild ductal epithelial hyperplasia (arrow) in some ducts. Group 7(chry.HD/NMU) (I) showing nearly normal structure of the mammary ducts. However, mild proliferation of lining epithelial cells of few ducts (arrow) still be seen (H\&E; A-I X400). 
Microscopic abnormalities observed in groups $6 \& 7$ that were protected by low or high dose of chrysin were strongly inhibited as, respectively, compared to group3. In group 6 focal regions of mild ductal epithelial hyperplasia were still detected in some ducts (Figure $1 \mathrm{H}$ ); however, in group7 nearly normal structure of the majority of the mammary ducts was observed except for few ducts in which there was mild epithelial proliferation (Figure 1I).

\subsection{Discussion}

Results obtained in the present study indicated that preneoplastic disorders induced by NMU injection (groups2 \& 3) caused significant increase in WBC count and the percentage of differential leukocyte types (monocytes and granulocytes).These results are in agreement with Chang et al. (2012); Abdel-Moein et al. (2013) and Yaacob et al. (2015) who observed significant elevation in the number of WBCs in NMU-treated rats. In contradiction with the report of Hoshyer et al. (2015) who observed significant decrease in lymphocytes and neutrophils in both NMU positive control groups. Reduced lymphocyte \% in NMU injected rats may be attributed to the principal mechanism of tumor immunity that is killing of tumor cells by CD8+ cytotoxic T-lymphocyte (Akinbami et al., 2013). Rochet et al. (2012) have stated that the inflammatory process that takes place during cancer development and progression are, in part, reflected in abnormalities of the WBC count. The decrease in PLT count presently detected is in accordance with Hoshyer et al. (2015) who observed significant decrease in PLT count in NMU-treated rats. However, Yaacob et al. (2015) demonstrated significant increase in PLT count of NMU-induced rat mammary tumor model.

From the present work it seems that, all rats injected with NMU and consumed chrysin for treatment (groups4\& 5) or protection (groups 6 \&7) exhibited significant decrease in WBC count as compared to rats injected in both positive controls (groups $2 \& 3$ ). The chrysin protected groups $6 \& 7$ brought back the PLT, WBC count and the monocytes $\%$ to near normal levels. Chrysin which is a phytoestrogen has been reported to show estrogenic effects. Estrogen exert an anti-inflammatory effect by down regulation of the expression of adhesion and chemokine molecules in response to inflammation in many animals (Ugochukwu et al.,2008).

The study of Sridhar et al. (2010) showed that WBC count and differential leukocyte count were significantly increased (except for lymphocytes) in Dalton's lymphoma. Treatment with chrysin brought back the WBC count more or less to normal levels.

Results in table (2) shows that benign proliferative lesions induced by NMU injection (groups2 \&3) caused significant reduction in $\mathrm{Hb}, \mathrm{MCH}$ and $\mathrm{MCHC}$ levels and significant elevation in MCV and RDW\% levels compared to control group. Similar effect of NMU on $\mathrm{Hb}$ concentration had been reported by Abdel-Moein et al. (2013). Furthermore, Yaacob et al. (2015) found decrease in $\mathrm{Hb}, \mathrm{MCHC}$ and marginal elevation of red cell size parameters, $\mathrm{MCV}, \mathrm{MCH}$ and $\mathrm{RDW} \%$ in the NMU-injected rats.

Decrease in $\mathrm{Hb}$ might be due to the destruction of RBCs directly or to the production of excess amount of free radicals (Schoniger-Hekele et al., 2010). Furthermore, Sridhar et al.(2010) attributed the decrease in $\mathrm{Hb}$ to iron deficiency or to hemolytic or myelopathic conditions. The cause behind the increase in RDW\% may be the increased immature RBCs or 
reticulocyte number (Soung et al., 2006).Free radicals can directly damage red blood cell membranes by peroxidation of membrane polyunsaturated fatty acids (Catala, 2009). It has been shown that thrombocytopenia in cancer patients is accompanied by anemia or leucopenia (Piatek and Akhtari, 2015). In the same concern, Akinbami et al. (2013) reported that BC patients had lower MCV, MCH and MCHC values and higher RDW than control.

Using two doses of chrysin for treatment or protection (groups 4, 5, $6 \& 7$ ) induced non-significant elevation in $\mathrm{Hb}$ concentration, $\mathrm{MCH}$ and $\mathrm{MCHC}$ levels and significant reduction in MCV and RDW\% compared to NMU groups. This indicates that chrysin possess protective action on hemopoietic system. These observations may be due to the fact that phytochemicals stimulate the formation or secretion of erythropoietin in the stem cells of animals in the bone marrow to produce RBCs (Ohlsson and Aher, 2009).In addition, chrysin may increase absorption of food and enhance iron and vitamin B12 absorption or stimulate erythropoiesis (Borawska et al., 2014).

Data in table (3) demonstrated that serum CRP and CEA levels were significantly elevated in both positive controls (groups $2 \& 3$ ) as compared to negative control (group1). The values of CRP and CEA in group3 were elevated more than in group2, which may be due to the fact that the duration between NMU administration and termination of the experiment was shorter in group3 than in group2 so the toxic effect was more evident in this group. Also, may be due to beginning appearance of preneoplastic cells generation leading to liberation of CEA and CRP from recent active inflamed affected cells .Furthermore, the present study reported that injection with NMU caused significant decrease in the level of serum $E_{2}$ as compared to control.

The elevated CRP may be attributed to the inflammatory cytokine interleukin-6 (il-6) that originating from the site of inflammation or the oxidative stress leads to NF- $\mathrm{K}_{\mathrm{B}}$ activation that triggers the hepatic production of CRP, a biomarker for chronic inflammation (Gabay and Kushner, 1999). Il-6 has been found to play an important role in various tumor behaviors, including proliferation and differentiation of tumor cells (Suchi et al, 2011), invasion and growth of malignancies (Santer et al., 2010), and cell migration and attachment leading to metastasis (Sierra, 2005).

Based on the studies of Allin et al. (2011) and Guo et al. (2013) a positive association between elevated levels of CRP and BC prognosis had been reported. Similarly, the results of Ahmed et al. (2015) regarding CRP level in Egyptian female, revealed a significant increase in its level in females with $\mathrm{BC}$ as compared to the healthy control.

CEA, a tumor marker is a reliable marker that is secreted by breast tumor into the serum in high levels. Its high value is strongly suggestive of the presence of mammary gland cancer. It was found that serum from individuals with various carcinomas including breast carcinoma had higher levels of CEA than healthy individuals (Park et al., 2014).The reduction of tumor mass in female patients developed a ductal carcinoma was evidenced by a continuing decline of CEA tumor marker serum level (Meiners et al., 2011). The study of Abdel-Moein et al. (2013) showed that injection of NMU for BC induction caused significant elevation in CEA and estrogen hormone levels compared to control group. Also, Rengarajan et al. (2015) showed that rats bearing $\mathrm{BC}$ induced by DMBA have elevated level of $\mathrm{E}_{2}$ as compared to 
control. The explanation for these conflicting findings with our results may be related to the difference in the age of the injected rats and the duration of the experiment.

The present work revealed that CRP and CEA levels were significantly decreased in treatment (groups4 \&5) and protective (groups 6 \&7) groups compared to their positive controls (groups $2 \& 3$ ). It's clear that CRP and CEA values of rats received high dose of chrysin as protection nearly approach those of the control group and subsequently suppresses precancerous lesions during NMU treatment. Meanwhile, the $\mathrm{E}_{2}$ level in treatment and protective groups was significantly elevated mostly closer to that of control. The apparent protective effect of chrysin, i.e. pretreatment with phytoestogen may be through the reduction in ER $\alpha$ than $E R \beta$ and then reduction in $\operatorname{ER} \alpha / \operatorname{ER} \beta$ should initiate less nuclear receptor sites for estrogen binding resulting in fewer proliferated mammary tumor (Cherdshewasart et al., 2007). Furthermore, flavonoids have protective effects in estrogen-dependent breast cancer by binding to estrogen receptor and modulating estrogen metabolism (Takemura et al., 2013). $\mathrm{E}_{2}$ is the most active estrogen which regulates the growth, differentiation, and physiology of the reproductive process through the estrogen receptor (Rengarajan et al., 2015). In accordance with these findings, Woo et al. (2005) indicated that chrysin exerts anti-inflammatory activity through down regulation the expression of cyclooxygenase-2 (COX-2). Prolonged inhibition of COX-2 caused lower levels of CRP (Bogaty et al., 2004).

It is well known that normal serum contains only trace activity of arginase. Arginase converts L-arginine to L-ornithine, which is a precursor for the biosynthesis of aliphatic polyamines, all of which are essential for cell growth and proliferation and facilitate all the steps of protein synthesis. Our findings provided significant increase in the activity of serum arginase enzyme in rats treated with NMU (groups $2 \& 3$ ). The increase in the arginase enzyme activity appears to participate in increased polyamine formation. All these molecules are relevant to the process of tumorigenesis (Delage et al., 2010;Kaplan et al., 2012).

The present results are in well accordance with the previous findings of polat et al. (2003) and Geyikli et al. (2012) according to which the arginase activity was elevated in the serum of women with BC in comparison to healthy women. It seems also in the present study that consumption of chrysin as treatment (groups $4 \& 5$ ) brought back the arginase activity to normal levels in comparison to the protective (groups $6 \& 7$ ). This inhibitory action exhibited by chrysin might be due to two phenolic hydroxyl groups on its molecular structure at positions 5 and 7, which can neutralize the effect of free radicals generated during DMBAinduced mammary carcinogenesis (Manjolin et al., 2013) or directly involved in decreasing ornithine decarboxylase activity by affecting genes encoding ornithine decarboxylase leading to decreased polyamine synthesis (Cho et al., 2015).

Cells and biological fluids have a series of enzymatic and non-enzymatic protective antioxidant mechanisms; acting together to protect the cells from oxidative damage and prevent the formation of radicals. Catalase (CAT) is a glycoprotein present in the antioxidant defense system of all cells and organelles and transforming $\mathrm{H}_{2} \mathrm{O}_{2}$ to $\mathrm{H}_{2} \mathrm{O}$ and $\mathrm{O}_{2}$. GST catalyze the conjugation of reactive chemicals with GSH and play a major role in protecting cells. Oxidative stress, an imbalance in oxidant and antioxidant status, has been implicated in the pathogenesis of several cancers including mammary cancer (Kolanjiappan and Manoharan, 2005). The results of the present study suggested that the activity of GST and CAT were significantly decreased in 
the serum of rats after injection with NMU (groups $2 \& 3$ ). This may be due to exhaustion of these enzymes in the removal of hydrogen peroxide induced by the abnormal proliferative cells. Our results are in line with the findings of Mallikarjuna et al. (2003) who observed significant depletion in GST (23\%) and CAT (20\%) activities in NMU-treated rats compared to normal control animals.

It seems from the current study that, oral administration of chrysin either as treatment (groups $4 \& 5$ ) or protective (groups $6 \& 7$ ) agent significantly reversed the status of the CAT and GST enzymes. This depicts the possible role of chrysin on the attenuation of oxidative stress. The results suggest that chrysin has potent free radical scavenging property especially at the high protective dose $(250 \mathrm{mg} / \mathrm{kg}$ b.w.) which brought back these enzymes to normal levels. Chrysin might have either promote the metabolic activation of NMU or stimulate the activities of detoxification agents. It is well known that flavonoids are able to induce phase II detoxifying enzymes which are the major defense enzymes against electrophilic toxicants and oxidative stress, by regulation of genes encoding these phase II enzymes (Nerland, 2007) and preferably activates phase II over phase I(Tucker and Robard, 2008).

TAC determination may be better measurement of overall antioxidant status. Results of the present study showed that the level of TAC was significantly decreased by injection of NMU (groups $2 \& 3$ ) and a more severe reduction was observed in group2 in which rats received NMU at the beginning of the experiment. This may be related to an imbalance in oxidant and antioxidant status, implicated in the pathogenesis of mammary proliferative lesions. The depletion of TAC level was normalized upon pretreatment of NMU-injected rats with chrysin (groups $6 \& 7$ ).

It is clear from the present study that, the NMU injection (groups 2 \& 3) caused significant increase in MDA and NO levels compared to control group. The increase in lipid peroxidation (LPO) levels may be the result of reduction in antioxidant status or increase production of reactive oxygen species (ROS). ROS reacts with poly unsaturated fatty acids to induce the release of toxic and reactive aldehyde metabolites such as MDA, one of the end products of LPO. Our results agreed with Vegh and de Salamanca, (2007) who reported that there was a significant increase in NO concentration in rats injected with NMU when compared to controls. Also, Alexandrova et al., (2001) showed that the increased production of NO has a critical role in the development of cancer cells by the stimulation of angiogenesis and increased mutation. Additionally, Yeh et al. (2005) showed that the level of MDA in the blood of patients with BC was significantly higher than control.

Increased levels of LPO products and chronic induction of NO play a role in the early phases of tumor growth (Huang et al., 1999) and inflammation (Moncadaand Higgs, 1993). On the other hand, NO can cause DNA damage via the generation of peroxynitrite ( $\mathrm{ONOO}^{-}$) and $\mathrm{N}_{2} \mathrm{O}_{3}$.Peroxynitrite may potentially cause single strand DNA breaks through attack on the sugar-phosphate back bone. $\mathrm{N}_{2} \mathrm{O}_{3}$ can nitrosate amines to form $\mathrm{N}$-nitroamines, then alkylate DNA (Xu et al., 2002).

It was observed that chrysin significantly inhibited the lipid membrane damage and elevated the level of antioxidants as evidenced in the present study from the decreased levels of serum MDA and NO in the NMU-treated rats (groups 4, 5, 6 and 7). The levels of MDA and NO were significantly restored to normal levels in protective high dose group (group7). The results 
are in accordance with other investigators that chrysin as a chemoprotective agent clearly normalized and significantly decreased oxidative stress indices such as MDA and NO (Thiruvengadam and Glory, 2012;Rehman et al., 2014).

In the present study, histopathological examination of the mammary glands of postmenopausal female rats treated with NMU showed a number of lesions ranged from sloughing of epithelial cells into the duct, simple ductal hyperplasia to benign atypical intraductal hyperplasia. The relevance of these findings is that intraductal hyperplasias are considered to be the precursors of carcinomas both in rodents and humans (Singh et al., 2000; Murray et al., 2007).

The results presented here are consistent with that reported in literatures review data. Earlier studies demonstrated that in experimental model of mammary carcinogenesis in female Sprague-Dawley rats induced by two intrajugular injection of MNU (50 mg/kg), beginning at 4449 days of age, the accumulation of p53 protein (tumor supressor gene) in cell was demonstrated in 22 from 37 rat mammary tumors. These results indicate that elevated cellular content of p53 is a common event in invasive palpable mammary tumors induced by NMU in this model system (Crist, 1996). Also, treatment of rats with chemical carcinogens such as NMU resulted in the development of intraductal hyperplasias, intraductal carcinomas in situ (CIS) and adenocarcinomas. Intraductal hyperplasias are believed to be the precursor lesion for both CIS and adenocarcinomas (Thompson et al.,1998). Also, Chan et al. (2005) showed that in NMUinduced mammary tumors in rats, the majority of tumors were identified as in situ ductal carcinomas with papillary and/or cribriform characteristics and they added that mutation of the H-ras gene in codon 12 has been implicated in the pathogenesis of NMU-induced tumors. Recently, the study of Abdel-Moein et al. (2013) showed that the histopathological features of tumor developed in rats injected by MNU were anaplastic activity in the lining epithelium associated with cystic dilatation in some of them as well as inflammatory cells infiltration in stromal connective tissue and categorized under adenocarcinoma.

In this study, oral administration of phytoestrogen(chrysin) as treatment induced partial reduction of ductal epithelial cell proliferation. Meanwhile, using chrysin as protection resulted in marked suppression of this benign epithelial cell proliferation. Using the high dose of chrysin was more effective than using low dose. In support of this, Srinivasan and Manoharan, (2011) showed that chrysin significantly suppressed the abnormal cell proliferation and inhibit tumor formation in DMBA-treated rats. The authors attributed these features to the antioxidant efficacy of chrysin allowing it to neutralize the increase in free radicals caused by DMBA. Also, Yang et al. (2014) demonstrated that inhibiting the Akt signal pathway might play a central role in chrysin-induced antimetastatic activities in triple-negative breast cancer (TNBC) cells by regulating matrix metalloproteinase (MMP) and epithelial-mesenchymal transition. More recently, in vitro and in vivo models have shown that chrysin inhibits cancer growth through various mechanisms including induction of apoptosis, alteration of cell cycle and inhibition of angiogenesis, invasion and metastasis without causing any toxicity and undesirable side effects to normal cells. This broad spectrum of antitumor activity in conjunction with low toxicity underscores the translational value of chrysin in treating breast cancer (Kasala et al., 2015).

These findings indicated that chrysin is found to be a potent antioxidant which ameliorates the adverse effects of NMU especially when given as protective with a high dose 
(250 mg/kg b.w.). Histopathological observations also correlated with the biochemical parameters and further supported the protective effects of chrysin against NMU-induced breast tissue damage.

\section{Conclusion}

Phytoestrogens may attenuate the severity of benign proliferative disorders in mammary glands of postmenopausal female rats, especially when consumed for a while before the incidence of lesions.

\section{References}

Abdel-Moein NM, Abo El-Ella FM, Youssef MH, Ahmed AM, Eassawy MT, Farroh KY. Effect of vitamin $\mathrm{E}$ injection on rats induced with breast cancer and their relation to bone disturbance. J. Biol. Chem. Environ. Sci. 8(3): 351-367 (2013).

Abeyounis CJ, Milgrom F. Studies on carcinoembryonic antigen. Int. Arch. Allergy Appl. Immunol. 43(1): 30-38 (1972).

Aebi H.. Catalase in vitro. Methods Enzymol. 105:121-126(1984).

Ahmed SA, Hamed MA, Omar OS. Clinical utility of certain biomarkers as predictors of breast cancer with or without metastasis among Egyptian females. Tumor Biol. 36 (2):815-822 (2015).

Akinbami A, Popoola A, Adediran A, Dosunmu A, Oshinaike O, Adebola P, Ajibola S., Full blood count pattern of pre-chemotherapy breast cancer patients in lagos, Nigeria. Caspian $\mathbf{J}$. Intern. Med. 4(1): 574-579(2013).

Alexandrova R, Mileva M, Zvetkova E. Nitric oxide and cancer(minireview). Exp. Pathol. Parasitol. 4: 13-8.(2001).

Alipour S, Jafari-Adli S, Eskandari A. Benefits and harms of phytoestrogen consumption in breast cancer survivors. Asian Pac. J. Cancer Prev. 16 (8): 3091-3096 (2015).

Allin KH, Nordestgaard BG, Flyger H, Bojesen SE. Elevated pretreatment levels of plasma Creactive protein are associated with poor prognosis after breast cancer: a cohort study. Breast Cancer Research 13 (3): 1-13 (2011).

Allred CD, Allred KF, Ju YH, Clausen LM, Doerge DR, Schantz SL, Korol DL, WalligMA,Helferich WG. Dietary genistein results in larger NMU-induced, estrogendependent mammary tumors following overiectomy of Sprague-Dawely rats. Carcinogenesis 25(2): 211-218 (2004).

Batzer F. Hormonal evaluation of early pregnancy. Fertil. Steril. 34:1-13 (1980).

Biglia N, Defabiani E, Ponzone R, Mariani L, D Marenco D, Sismondi P. Management of risk of breast carcinomain postmenopausal women. Endocrine-Related Cancer. 11: 69-83 (2004).

Bogaty P, Brophy JM, Noel M, Boyer L, Simard S, Bertrand F, Dagenais GR. Impact of prolonged cyclooxygenase-2 inhibition on inflammatory markers and endothelial function in patients with ischemic heart disease and raised C-reactive protein: a randomized placebocontrolled study. Circulation 110(8): 934 - 939 (2004).

Borawska MH, Markiewicz-Zukowska RM, Sawicka D, Naliwajko SK, Socha K, Omeljaniuk W, Car H. Effect of chrysin on haematological parameters in rats.Farmacia. 62 (2): 390-399 (2014). 
Catala A . Lipid peroxidation of membrane phospholipids generates hydroxyalkenals and oxidized phospholipids active in physiological and/or pathological conditions. Chem. Phys. Lipids 157:1-11 (2009).

Chan MM, Lu X, Merchant FM, Iglehart JD, Miron PL. Gene expression profiling of NMUinduced rat mammary tumors: cross species comparison with human breast cancer. Carcinogenesis 26(8): 1343-1353 (2005).

Chang YC, Hsu JD, Lin WL,Lee YJ, Wang CJ. High incidence of acute promyelocytic leukemia specifically induced by $\mathrm{N}$-nitroso-N-methylurea (NMU) in Sprague-Dawley rats. Arch.Toxicol. 86 (2):315-327 (2012).

Cherdshewasart W, Panriansaen R, Picha P. Pretreatment with phytoestrogen-rich plant decreases breast tumor incidence and exhibits lower profile of mammary ER $\alpha$ and ER $\beta$. Maturitas 58 (2): 174-181 (2007)

Cho H, Yun CW, Park WK, Kong, JY, Kim KS, Park Y, Lee S, Kim BK. Modulation of the activity of pro-inflammatory enzymes, COX-2 and iNOS, by chrysin derivatives. Pharmacol. Res.49(1): 37-43 (2004)

Cho LY, Yang JJ, Ko KP, Ma SH, Shin A, Choi BY, Kim HJ, Han DS, Song KS, Kim YS, Chang SH, Shin HR, Kang D, Yoo KY, Park SK. Gene polymorphisms in the ornithine decarboxylase-polyamine pathway modify gastric cancer risk by interaction with isoflavone concentrations. Gastric Cancer 18(3):495-503 (2015)

Crist KA, Fuller RD, Chaudhuri B, Chaudhuri P, You M. Brief communication, P53 accumulation in N-nitroso-N-methylurea induced mammary tumors. Toxicol. Pathol. 24(3): 370-375 (1996)

Davis VL, Jayo MJ, Ho A,Kotlarczyk MP, Hardy ML, Foster WG, Hughes CL. Black cohosh increases metastatic mammary cancer in transgenic mice expressing c-erbb2. Cancer Res. 68 (20):8377-8383 (2008)

Delage B, Fennell DA, Nicholson L, McNeish I, Lemoine NR, Crook T, Szlosarek PW. Arginine deprivation and argininosuccinatesynthetase expression in the treatment of cancer. Int. J. Cancer 126(12):2762-2772 (2010)

Drury RA,Wallington EA. Carleton's Histological Techniques. $5^{\text {th }}$ Ed. New York, Oxford University Press, 126-133 (1980).

Ferlay J, Shin HR,Bray F, Forman D, Mathers C, Parkin DM. Estimates of worldwide burden of cancer in 2008. Int. J. Cancer 127(12): 2893-2917 (2010).

Gabay C, Kushner I. Acute-phase proteins and other systemic responses to inflammation. $\mathbf{N}$. Engl. J. Med. 340(6): 448 - 454 (1999).

Gambelunghe C, Rossi R, Sommavilla M, Ferranti C, Rossi R, Ciculi C, Gizzi S, Micheletti A, Rufini S. Effects of chrysin on urinary testosterone levels in human males. J. Med. Food 6(4):387-390 (2003).

Geyikli I, ceylan NO,Camci C. Arginase activity and nitric oxide levels may be considered as tumor markers in breast cancer. Journal of Applied Pharmaceutical Science. 2(10):31-34 (2012).

Green LC, Wagner DA, Glogowski J, Skipper PL, Wishnok JS, Tannenbaum SR. Analysis of nitrate, nitrite \& $\left[{ }^{15} \mathrm{~N}\right]$ nitrate in biological fluids. Anal. Biochem. 126(1): 131-138 (1982).

Guo Y, Pan L, Du CJ, Ren DQ, Xie XM. Association between C-reactive protein and risk of cancer: a meta-analysis of prospective cohort studies. Asian Pacific J. Cancer Prev 14(1): 243-248 (2013).

Habig WH, Pabst MJ, Jakoby WB. Glutathione-S-transferases: The first enzymatic step in mercaputic acid formation. J. Biol. Chem. 249 (22): $7130-7139$ (1974). 
Hoshyar R, Mohaghegh Z, Torabi N. Abolghasemi A. Antitumor activity of aqueous extract of Ziziphus Jujube fruit in breast cancer: an in vitro and in vivo study. Asian Pacific Journal of Reproduction 4 (2): 116-122 (2015).

Huang YL, Sheu JY, Lin TH. Association between oxidative stress and changes of trace elements in patients with breast cancer. Clin.Biochem. 32(2):131-136 (1999).

Kaplan I, Aydin Y, Bilen Y, Genc F, Keles MS, Eroglu A. The evaluation of plasma arginine, arginase and nitric oxide levels in patients with esophageal cancer. Turk.J. Med. Sci. 42 (3):403-409 (2012).

Kasala ER, Bodduluru LN, Madana RM, V AK, Gogoi R, Barua CC. Chemopreventive and therapeutic potential of chrysin in cancer: mechanistic perspectives. Toxicol.Lett.4;233(2):214-225 (2015).

Kawase A, Matsumoto Y, Hadano M, Ishii Y, Iwaki M. Differential effects of chrysin on nitrofurantoin pharmacokinetics mediated by intestinal breast cancer resistance protein in rats \&mice. J. Pharm. Pharma. Sci. 12(2): 150-163 (2009).

Khoo BY, Chua SL, Balaram P..Apoptotic effects of chrysin in human cancer cell lines. Int. J. Mol. Sci. 11(5): 2188-2199 (2010).

Kolanjiappan, K, Manoharan, S. Chemopreventive efficacy and anti-lipid peroxidative potential of JasminumgrandiflorumLinn. on 7,12-dimethylbenz(a)anthracene-induced rat mammary carcinogenesis. Fundam. Clin. Pharmacol. 19(6):687-693 (2005).

Koracevic D, KoracevicG,Djordjevic V, Andrejevic S, Cosic V. Method for the measurement of antioxidant activity in human fluids. J. Clin. Pathol. 54(5):356-361 (2001).

Lillie RD. Histopathological techniques and practical histochemistry, $3^{\text {ed }}$ Ed. McGraw-Hill Co., New York, USA, 501 (1954).

Mallikarjuna GU, Dhanalakshmi S, Raisuddin S, Rao AR. Chemomodulatory influence of Ferula asafoetida on mammary epithelial differentiation, hepatic drug metabolizing enzymes, antioxidant profiles and $\mathrm{N}$-methyl-N-nitrosourea-induced mammary carcinogenesis in rats. Breast Cancer Res. Treat. 81(1): 1-10 (2003).

Manjolin LC, dos Reis MB, MaquiaveliCdo C, Santos-Filho OA, da Silva ER. Dietary flavonoids fisetin, luteolin and their derived compounds inhibit arginase, a central enzyme in Leishmania (Leishmania) amazonensis infection. Food Chem. 141(3): 2253-2262 (2013).

Meeran SM, Patel SN, Li Y, Shukla S, Tollesfsbol TO. Bioactive dietary supplements reactivate ER expression in ER-negative breast cancer cells by active chromatin modifications. PLoS One. 7(5):e37748 (2012)

Meiners C. Clinical response of metastatic breast cancer to multi-targeted therapeutic approach: a single case report. Cancers (Basel). 3(1): 1454-1466 (2011).

Mellerup B. Colorimeteric method for rapid determination of serum arginase. Clin. Chem. 13(10): 900-908 (1967).

Mense SM, Hei TK, Ganju RK, Bhat HK. Phytoestrogens and Breast Cancer Prevention: Possible Mechanisms of Action. Environ. Heath Perspect. 116 (4): 426-433 (2008).

Moncada S, Higgs A. The L-arginine-nitric oxide pathway. N. Engl. J. Med. 329 (27):20022012 (1993).

Moutsatsou P. The spectrum of phytoestrogens in nature: our knowledge is expanding. Hormones (Athens). 6(3): 173-193 (2007).

Murray TJ, Maffini MV, Ucci AA, SonnenscheinC,Soto AM. Induction of mammary gland ductal hyperplasias and carcinoma in situ following fetalbisphenolAexposure. Reprod.Toxicol. 23(3): 383-390 (2007). 
National Research council, NRC.Nutrient Requirements of Laboratory Animals $4^{\text {th }}$ revised edition. National Academy Press, Washington, D. C., Chapter 2, 11-79 (1995).

Nerland DE. The antioxidant/electrophile response element motif. Drug.Metab.Rev.39(1):235248 (2007).

Ogur R, Tekbas OF. A commonly used pesticide Endosulfan in diet could cause hepatomegaly and kidney tumor when combined with nitrosamines. Environmental Earth Sciences. 599605 (2011).

Ohkawa H, OhishiN, Yagi K. Assay for lipid peroxides in animal tissues by thiobarbituric acid reaction. Anal.Biochem. 95(2) : 351-358 (1979).

Ohlsson A, Aher SM. Early erythropoietin for preventing red blood cell transfusion in preterm and/or low birth weight infants. J. Diet Suppl. 6(3): 227-251 (2009).

Okamura JM, Miyagi JM, Terada K, Hokama Y. Potential Clinical Applications of C-Reactive Protein. J. Clin. Lab.Anal. 4(3):231-235 (1990).

Park BJ, Cha MK, Kim IH. Thioredoxin 1 as a serum marker for breast cancer and its use in combination with CEA or CA 15-3 for improving the sensitivity of breast cancer diagnoses. Bio. Med. Central. Res. Notes. 7:7-19 (2014).

Piatek C., Akhtari M. Thrombocytopenia: optimizing approaches in cancer patients. Oncology (Williston Park). 29(4):297-298 (2015).

Pilsakova L, Riecansky I, Jagla F.The physiological actions of isoflavone phytoestrogens. Physiol. Res. 59(5):651-664 (2010).

Pitkin J. Alternative and complementary therapies for the menopause. Menopause Int. 18(1): 20-27 (2012).

Polat MF, Taysi S, Polat S, Boyük A, Bakan E. Elevated Serum Arginase Activity Levels in Patients with Breast Cancer.Surg. Today 33(9):655-661 (2003).

Rehman MU, Ali N, Rashid S, jain T, Nafees S, Tahir M, Khan AQ, Lateef A, Khan R, Hamiza OO, KazimS Qamar W, Sultana S. Alleviation of hepatic injury by chrysin in cisplatin administered rats: probable role of oxidative and inflammatory markers. Pharmacol. Rep. 66 (6): 1050-1059 (2014) .

Rengarajan T, Nandakumar N, Rejendarn P, Ganesh MK, Balasubramanian MP, Nishigaki I. Dpinitol mitigates tumor growth by modulating interleukins and hormones and induces apoptosis in rat breast carcinogenesis through inhibition of $\mathrm{NF}_{\mathrm{k}} \mathrm{B}$. J. physiol. Biochem. 71(2): 191-204 (2015).

Rochet NM, SvetomirBS.,Markovic N, Porrata LF. The role of complete blood cell count in prognosis - watch this space. Hematology 8(1): 76-82 (2012).

SahaRoy S, Vadlamudi RK. Role of Estrogen receptor signaling in breast cancer metastasis. Int. J. Breast Cancer 2012:1-8 (2012).

Santer FR, Malinowska K, Culig Z, Cavarretta IT. Interleukin-6 trans-signalling differentially regulates proliferation, migration, adhesion and maspin expression in human prostate cancer cells. Endocr. Relat. Cancer 17(1):241-253 (2010).

Schoniger-Hekele M, Müller C. Pilot study: rapamycin in advanced hepatocellular carcinoma. Aliment. Pharmacol. Ther. 32(6):763-768 (2010).

Setchell KD. Soy isoflavones - benefits and risks from nature's selective estrogen receptor modulators (SERMs), J. Am. Coll. Nutr. 20(5 Suppl): 354S-362S (2001).

Sierra A. Metastases and their microenvironments: linking pathogenesis and therapy. Drug Resist. Updat. 8(4): 247-257 (2005). 
Singh M, McGinley JN, Thompson HJ. A comparison of the histopathology of premalignant andmalignant mammary gland lesions induced in sexually immature rats with those occurring in the human. Lab. Invest. 80(2):221-231 (2000).

Soung DY, Patade A, Khalil DA, Lucas EA, Devareddy L, Greaves KA, Arjmandi BH. Soy protein supplementation does not cause lymphocytopenia in postmenopausal women. Nutr. J. 5(12):1-6 (2006) .

Sridhar RK, Tarun KG, Surender RP, Harikiran L, Pradeep BK, Rajesh E. Evaluation of antitumour and cytotoxic activity of methyl hesperidin and chrysin. Scientific Journal of Pharmacy. 1(1): 10-15 (2010).

Srinivasan R, Manoharan S. Chemopreventive potential of chrysin in 7,12dimethylbenz(a)anthranece induced mammary carcinogenesis in Sprague-Dawely rats. Journal of Cell and Tissue Research 11(3): 2909-2918 (2011).

Suchi K, Fujiwara H, Okamura S, Okamura H, Umehara S, Todo M. Overexpression of interleukin-6 suppresses cisplatin-induced cytotoxicity in esophageal squamous cell carcinoma cells. Anticancer Res. 31(1):67-75 (2011).

Takemura H, Sakakibara H, Yamazaki S, Shimoi K. Breast cancer and flavonoids - a role in prevention. Curr. Pharm. Des. 19(34):6125-6132 (2013).

ThiruvengadamD, Glory MD. Potential chemopreventive role of chrysin against Nnitrosodiethylamine- induced hepatocellular carcinoma in rats. Biomedicine \& Preventive Nutrition 2(2): 106-112 (2012).

Thompson HJ, Adlakha H. Dose responsive induction of mammary gland carcinomas by the intraperitoneal injection of 1-methyl-1-nitrosourea. Cancer Res. 51(13): 3411-3415 (1991).

Thompson HJ, Mc-Ginley JN, Wolfe P, Singh M, Steele VE, Kelloff GJ. Temporal sequence of mammaryintraductal proliferations, ductal carcinomas in situ and adenocarcinomas induced by 1-methyl-1-nitrosourea in rats. Carcinogenesis 19(12):2181-2185 (1998).

Tsubura A, Lai YC, Miki H, Saski T, Uehara N, Yuri T. Yoshizawa K. Animal models of Nmethyl-N-nitrosurea-induced mammary cancer and retinal degeneration with special emphasis on therapeutic trials. In Vivo 25(1): 11-22 (2011).

Tucker G, Robards K. Bioactivity and structure of biophenols as mediators of chronic diseases. Crit. Rev. Food Sci.Nutr. 48(10):929-966 (2008).

Ugochukwu CNC, Ebong PE, Eyong EU. Biochemical implication of long term administration of Halofantrine Hydrochloride (Halfan) on estradiol level of female wistar rats. Pakistan J. of Nutr. 7(2): 227-230 (2008).

Vegh I, de Salamanca RE. Prolactin, TNF alpha and nitric oxide expression in nitroso-Nmethylurea- induced-mammary tumors. J. Carcinog. 6(18):1-8 (2007).

Woo KJ, Jeong YJ, Inoue H, Park JW, Kwon TK. Chrysin suppresses lipopolysaccharideinduced cyclooxygenase-2 expression through the inhibition of nuclear factor for IL-6 (NFIL6) DNA-binding activity. FEBS Lett. 579(3):705-711 (2005).

Woodman OL, Chan Ech. Vascular and anti-oxidant actions of flavonols and flavones. Clin. Exp. Pharmacol. Physiol. 31(11): 786-790 (2004).

Xu W, Liu LZ, Laizidou M, Ahmed M, Charles IG. The role of nitric oxide in cancer. Cell Res. 12(5-6):311-320 (2002).

Yaacob NS, Yankuzo HM, Devaraj S, Wong JK, Lai C. Antitumor action, clinical biochemistry profile and phytochemical constituents of pharmacologically active fraction of S. Crispus in NMU-induced rat mammary tumor model. PlosOne 10(5): 1-20 (2015). 
Yeh CC, Hou MF, Tsai SM, Lin SK, Hsiao JK, Huang JC, Wang LH, Wu SH, Hou L, Ma H, Tsai LY. Superoxide anion radical, lipid peroxides and antioxidant status in the blood of patients with breast cancer. Clin.Chim.Acta. 361(1-2):104-111 (2005).

Yang B, Huang J, Xiang T, Yin X, Luo X, Huang J, Luo F, Li H, Li H, Ren G. Chrysin inhibits metastatic potential of human triple-negative breast cancer cells by modulating matrix metalloproteinase-10, epithelial to mesenchymal transition, and PI3K/Akt signaling pathway. J. Appl.Toxicol. 34(1):105-12 (2014).

Group1 (Negative control): rats received i.p. injections of physiological saline and sarved as control . 
الملخص باللغة العربية

\section{الدورالبيوكيميائى للفيتواستروجين( الكريسين) ضد اعراض الزيادة فى تكاثر الخلايا المحدثة فى اناث الفئران في سن اليأس.}

أمل عثماوي أحمد القرش 1 , حنان ححمد فتحى عبد الوهاب1 , هالة فهمى عبد اللهُ2, نجوى إبر اهيم يحيى حسنين , نهاد نعيم حامد شوشة ألمل 1.قسم الكيمباء الحيوية و التغذية. كلية البنات. جامعة عين شمس.

2 ـ قسم علم الحيوان. كلية البنات. جامعة عين شمس الته

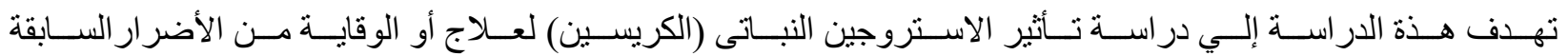

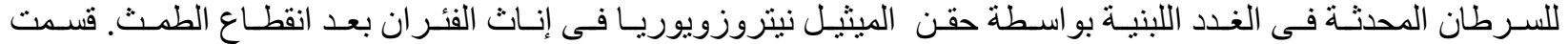

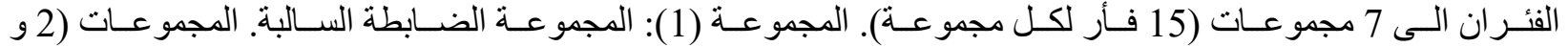

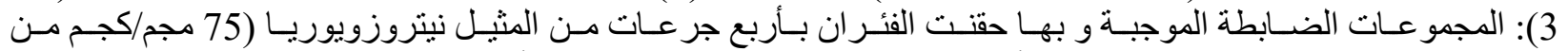

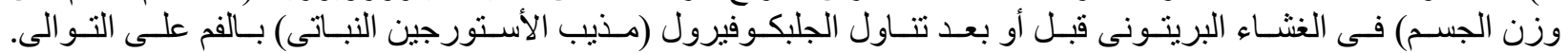

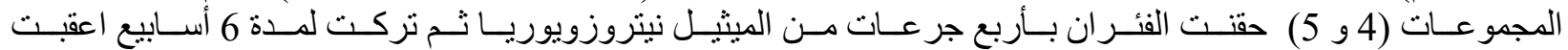

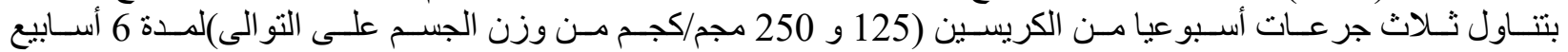

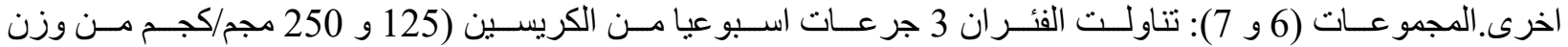

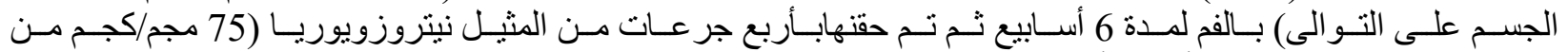
وزن الجسم) ثم تركت لمدة 6 أسابيع أخرى.

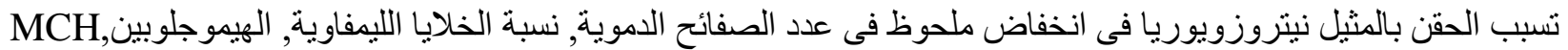
مستوى الاستر اديول و كمية مضادات الأكسدة و كذللك مدى نشاط انزيم الكاتلاز و الجلوتاثيون اس ترانسفيريز . و و MCV, RDW\%, كذلك اثبتت النتائج زيادة ملحوظة في عدد كر ات الدم البيضاء, نسبة الجرنيولوسيت , نسبة المونوسيت الإنيت بالاضافة إلى زيادة نشاط إنزيم الأرجينيز.

استنتج من الدراسة ان استخدام الكريسين كعلاج او كوقاية يخفف الأثار الحادة للحقن بالميثيل نيتروزويوريا و كذلك الأثار

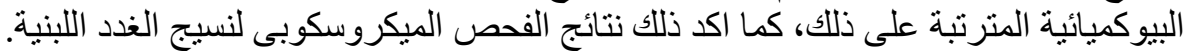

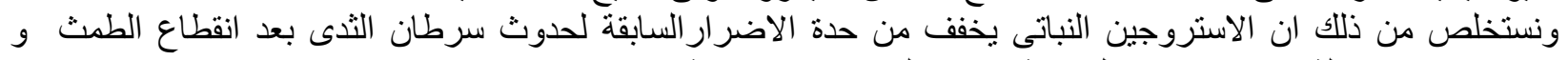

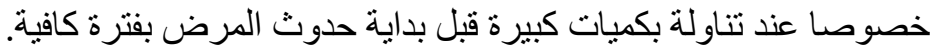

